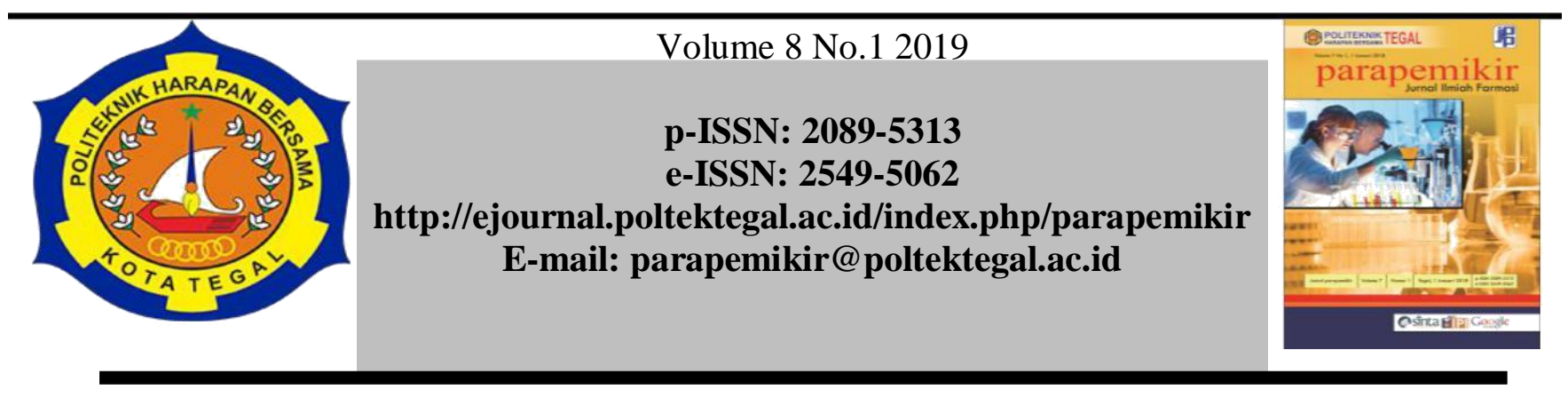

\title{
Pengaruh Suplementasi Seng Sulfat 40 mg/hr Selama 12 Minggu terhadap Kadar Sitokin proinflamasi TNF- $\alpha$, IL-1 $\beta$ dan IL-6 Pada Penderita Kusta Multi Basiler
}

\author{
Joko Kurnianto ${ }^{1}$, Hertanto $\mathrm{WS}^{2}$, Prasetyowati ${ }^{3}$, Suharyo HS $^{4}$ \\ ${ }^{1,3,4}$ Fakultas Kedokteran, Universitas Diponegoro, Semarang Indonesia, ${ }^{2}$ Rumah Sakit Umum Suradadi, Tegal - \\ Jawa Tengah
}

\begin{tabular}{|c|c|}
\hline Article Info & Abstrak \\
\hline Article history: & \multirow{9}{*}{$\begin{array}{l}\text { Peran Seng sebagai anti oksidan dan anti inflamasi telah banyak dibuktikan zat ini } \\
\text { relatif murah dan mudah didapat oleh masyarakat, kadar seng serum pasien kusta dan } \\
\text { penderita reaksi kusta lebih rendah dibandingkan dengan orang sehat, dan sitokin } \\
\text { proinflamasi diantaranya TNF- } \alpha \text {, IL- } 1 \beta \text { dan IL- } 6 \text { berperan dalam mekanisme terjadinya } \\
\text { reaksi kusta. Penelitian mengenai pengaruh suplementasi seng pada penderita kusta } \\
\text { yang tidak mengalami reaksi belum banyak dilakukan. Tujuan : Menganalisis pengaruh } \\
\text { suplementasi Seng sulfat dosis } 40 \mathrm{mg} / \mathrm{hr} \text { selama } 12 \text { minggu terhadap kadar sitokin } \\
\text { proinflamasi TNF- } \alpha \text {, IL-1 } \beta \text { dan IL- } 6 \text { pada penderita Kusta tipe MB. Merupakan } \\
\text { penelitian eksperimen dengan pendekatan randomized control group pre and post test } \\
\text { design, subyek penelitian ini adalah penderita tipe MB sejumlah } 121 \text { pasien yang tidak } \\
\text { mengalami reaksi kusta, sampel diambil secara random sebanyak } 31 \text { pasien sebagai } \\
\text { kelompok suplementasi, dan } 31 \text { pasien sebagai kelompok kontrol. Dilakukan } \\
\text { pengukuran IMT, asupan makanan dengan metode recall, kadar Hb menggunakan }\end{array}$} \\
\hline $\begin{array}{l}\text { Received Desmber } \\
2018\end{array}$ & \\
\hline Received in & \\
\hline revised form & \\
\hline Desember 2018 & \\
\hline Accepted Januari & \\
\hline 2019 & \\
\hline Available online & \\
\hline January 2019 & \\
\hline $\begin{array}{l}\text { Kata kunci: } \\
\text { Suplementasi, } \\
\text { sitokin, Kusta tipe } \\
\text { MB }\end{array}$ & $\begin{array}{l}\text { Hematology Analizer, kadar seng serum menggunakan metode Atomic Absorbtion } \\
\text { spectrofotometry (AAS), kadar TNF- } \alpha \text {, IL-1 } \beta \text { dan IL- } 6 \text { menggunakan metode ELISA. } \\
\text { Analisa data menggunakan uji statistik korelasi chi-square dan uji beda rerata (mean). } \\
\text { Suplementasi Seng sulfat dosis } 40 \mathrm{mg} / \mathrm{hr} \text { selama } 12 \text { minggu pada penderita Kusta tipe }\end{array}$ \\
\hline & $\begin{array}{l}\text { MB mempertahankan penurunan kadar seng sebesar } 1,22 \mathrm{pg} / \mathrm{dL} \text { lebih tinggi dibanding } \\
\text { penderita kusta yang tidak mendapat suplementasi seng, menurunkan kadar sitokin IL- } \\
1 \beta \text { (p: } 0.032 \text { ) namun demikian secara statistik belum cukup bukti menurunkan kadar } \\
\text { sitokin TNF- } \alpha \text { (p: } 0.063 \text { ) dan IL-6 (p: } 0.389 \text { ). } \\
\text { Simpulan : Suplementasi Seng sulfat dosis } 40 \mathrm{mg} / \mathrm{hr} \text { selama } 12 \text { minggu pada penderita } \\
\text { Kusta tipe MB mempertahankan penurunan kadar seng serum, menurunkan kadar } \\
\text { sitokin proinflamasi IL-1 } \beta \text {. }\end{array}$ \\
\hline & abstract \\
\hline $\begin{array}{l}\text { Keywords: } \\
\text { Supplementation, } \\
\text { cytokines, leprosy } \\
\text { type } M B .\end{array}$ & $\begin{array}{l}\text { The role of zinc as an anti-oxidant and anti-inflammatory has been widely proven, this } \\
\text { substance is relatively inexpensive and easily available to the public. Serum zinc levels } \\
\text { of leprosy patients and patients with leprosy reactions are lower compared to healthy } \\
\text { people, and proinflammatory cytokines including TNF- } \alpha \text {, IL-1 } \beta \text { and IL- } 6 \text { play a role in } \\
\text { the mechanism of leprosy reactions. Research on the effect of zinc supplementation on } \\
\text { leprosy sufferers who have not experienced a reaction has not been done. Objective: To } \\
\text { analyze the effect of } 40 \mathrm{mg} / \text { day dose of zinc sulphate supplementation for } 12 \text { weeks } \\
\text { on the levels of proinflammatory cytokines and the incidence of reactions in type MB } \\
\text { leprosy patients. An experimental study with a randomized control group pre and post } \\
\text { test design approach, the subjects of this study were MB patients with } 121 \text { patients who } \\
\text { did not experience a leprosy reaction, the sample was taken randomly as many as } 31 \\
\text { patients as a supplementation group (treatment), and } 31 \text { patients as Control group. BMI }\end{array}$ \\
\hline
\end{tabular}




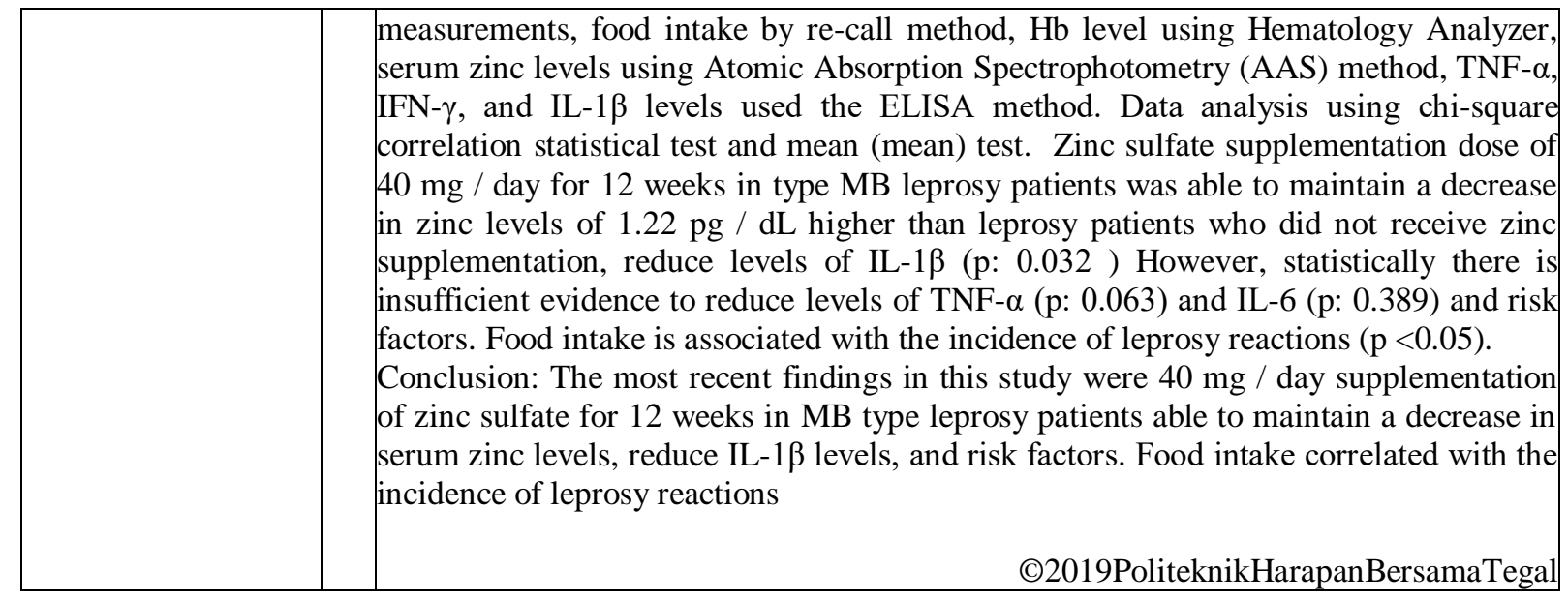

Alamat korespondensi:

Prodi DIII Farmasi Politeknik Harapan Bersama Tegal

Gedung A Lt.3. Kampus 1

Jl. Mataram No. 09 Kota Tegal, Kodepos 52122

Telp. (0283) 352000 


\section{Pendahuluan}

Kusta merupakan penyakit kronis yang disebabkan oleh infeksi bakteri Mycobacterium leprae $^{1}$ Penyakit ini menjadi penyebab utama deformitas dan disabilitas diantara penyakit menular lainnya yang menimbulkan stigma, gangguan psikosial dan ekonomi ${ }^{2,3}$

World Health Organization (WHO) pada tahun 2010 melaporkan bahwa Asia Tenggara merupakan daerah dengan tingkat prevalensi tertinggi yaitu 120.456 kasus tiap 10.000 populasi $^{4}$ Angka kejadian reaksi kusta baik tipe 1 maupun tipe 2 di dunia cukup tinggi, berdasarkan kajian di beberapa negara antara lain : Indonesia, Brazil, Nepal, Banglades dan India jumlah kasus kusta berkisar antara 16-56\%, untuk reaksi kusta tipe 1 pada kisaran $20-60 \%$, sedangkan reaksi kusta tipe 2 (ENL) sekitar 19-37\%. ${ }^{5-9}$ Angka kecacatan akibat kusta berkisar antara 20-30\% dari kasus baru, dan sebagian diantaranya memerlukan penanganan rehabilitasi. Angka kecacatan tingkat 2 penderita kusta di Indonesia pada tahun 2015 sebesar $10.07 \%$, di Jawa Tengah untuk tahun yang sama proporsi cacat tingkat 2 sebesar $8.1 \%$. Angka kecacatan penderita kusta di Kabupaten Tegal selama lima tahun terakhir cenderung meningkat, berturutturut dari tahun tahun 2011 sebesar $8.12 \%$, tahun 2012 sebesar $7.3 \%$, tahun 2013 sebesar $10.7 \%$ dan tahun 2014 sebesar $10.2 \%$, dan tahun 2015 sebanyak $12 \% .^{10-12}$

Kusta merupakan masalah kesehatan masyarakat pada negara berkembang dan sering dihubungkan dengan kemiskinan serta sering dikaitkan dengan kekurangan gizi. ${ }^{13,14}$ Status gizi kurang dapat disebabkan oleh asupan makanan yang tidak memadai baik dalam kuantitas maupun kualitas pangan. Individu dengan kusta lebih sering mengonsumsi sayur dan jarang mengkonsumsi protein hewani. Sebagian besar sayur bukan merupakan sumber zinc yang baik karena adanya phytate. Zat ini akan mengikat zinc sehingga zinc tidak bisa diabsorpsi oleh saluran cerna. Diet rendah protein dan kaya phytate berperan pada tingginya prevalensi defisiensi zinc di negara berkembang. ${ }^{15}$ Defisiensi zinc menyebabkan menurunnya imunitas berupa kegagalan sel makrofag dalam proses fagositosis dan menurunnya kemampuan sel-T untuk diferensiasi dan proliferasi.

Beberapa studi pada percobaan binatang dan pengamatan klinis pada manusia, keadaan nutrisi berperan pada perjalanan dan perkembangan penyakit kusta dan diantara elemen nutrisi tersebut, zinc merupakan trace elemen terpenting untuk pertumbuhan organ timus dan jaringan limfoid, yang berperan sebagai organ tempat diferensiasi dan maturasi sel-sel yang terlibat dalam imunitas seluler ${ }^{16}$.
Oleh karena itu menilai status seng dengan memberikan suplementasi dapat meningkatkan status gizi dan memperbaiki stres oksidatif yang dapat menjadi strategi efektif untuk pengobatan dan pengendalian kusta. ${ }^{17}$

Penurunan sistem kebal tubuh serta meningkatnya kejadian infeksi kusta dapat diakibatkan oleh rendahnya kadar zinc dalam tubuh. Zinc mampu berperan didalam meningkatkan respon tanggap kebal secara nonspesifik maupun spesifik. Sel makrofag yang berperan di dalam sistem tanggap kebal akan mengalami kendala dalam membunuh agen infeksi intraseluler, menurunnya produksi sitokin dan kendala dalam proses fagositosis. Respon imun yang terganggu menyebabkan terjadinya perubahan resistensi terhadap infeksi. Oleh karena itu, kecukupan mineral zinc perlu mendapat perhatian mengingat perannya didalam meningkatkan sistem kebal tubuh dan pengaruhnya terhadap kejadian infeksi.

Saat ini belum banyak literatur tentang faktor risiko Reaksi Kusta seperti : Status Gizi (Indeks Massa Tubuh (IMT), Status anemia/Kadar $\mathrm{Hb}$, Kadar Zinc), Koinfeksi, Stress Fisik/mental dan Asupan makanan pada penderita Kusta MB. Penelitian ini bertujuan menganalisis pengaruh suplemen-tasi Seng terhadap kadar sitokin proinflamasi dan kejadian reaksi kusta dengan melohat faktor risiko Indeks Massa Tubuh (IMT), Kadar Haemoglobin, Kadar Zinc, Riyawat Koinfeksi, dan Riwayat Asupan makanan, pada pasien kusta tipe MB. Penelitian ini diharapkan dapat berguna untuk program perbaikan status gizi khususnya kadar Seng pasien kusta serta sebagai bahan evaluasi program pencegahan dan penatalaksanaan reaksi kusta.

II. Metodologi Penelitian

Penelitian ini merupakan penelitian kuasi eksperimen dengan menggunakan randomized pre and post test control group design. Penelitian dimulai dari pengelompokan pasien berdasarkan diagnosis: kusta dengan reaksi dan kusta tanpa reaksi sebagai subyek penelitian. Penelitian ini dilakukan di 11 wilayah Puskesmas di Kabupaten Tegal pada bulan Januari-Mei 2018. Kriteria inklusi sampel pada penelitian ini adalah pasien laki-laki dan perempuan, usia 15-60 tahun, kusta tipe MB dalam pengobatan MDT, tanpa reaksi, dan bersedia untuk ikut dalam penelitian. Kriteria eksklusi sampel meliputi pasien wanita hamil dan menyusui, sedang reaksi kusta, konsumsi alkohol, gagal ginjal, pembedahan, luka bakar, multitrauma, fraktur, diabetes mellitus, penyakit autoimun, kondisi inflamasi selain reaksi kusta, sedang terapi imunosupresan selain kortikosteroid,serta pasien sudah released from treatment (RFT). Protokol 
penelitian ini telah mendapat persetujuan dari Komite Etik Penelitian Kesehatan (KEPK) Fakultas Kedokteran Universitas Diponegoro.

Subjek penelitian dipilih secara random dengan kelompok eksperimen adalah penderita kusta tipe MB dengan tanda klinis reaksi dan kelompok kontrol adalah penderita kusta MB tanpa reaksi. Pengumpulan data menggunakan kuesioner melalui anamnesa, wawancara, pemeriksaan fisik, serta pemeriksaan darah dan serum pada subjek kasus dan kontrol. Jumlah sampel 72 orang yang terdiri dari kelompok perlakuan 36 orang dan kelompok kontrol 36 orang. Selanjutnya pada kelompok kasus diberikan suplementasi Seng sulfat dosis $40 \mathrm{mg} /$ hari selama 12 minggu sedangkan pada kelompok kontrol hanya diberikan MDT saja. Analisa data menggunakan program SPSS for windows dengan uji Korelasi ChiSquare dan Uji t.

\section{HASIL DAN Pembahasan}

Pada awal pengambilan data, subjek penelitian berjumlah 73 partisipan namun sampai dengan akhir suplementasi Seng sulfat jumlah subjek yang memenuhi kriteria untuk dianalisa berjumlah 65 orang (kelompok perlakuan 31 pasien; kelompok kontrol 31 pasien). Karakteristik subjek penelitian baik kelompok perlakuan maupun kelompok kontrol dapat dilihat pada Tabel 1.

Tabel 1. Perbedaan Karakteristik Subyek antara Kelompok Perlakuan dan Kelompok Kontrol.

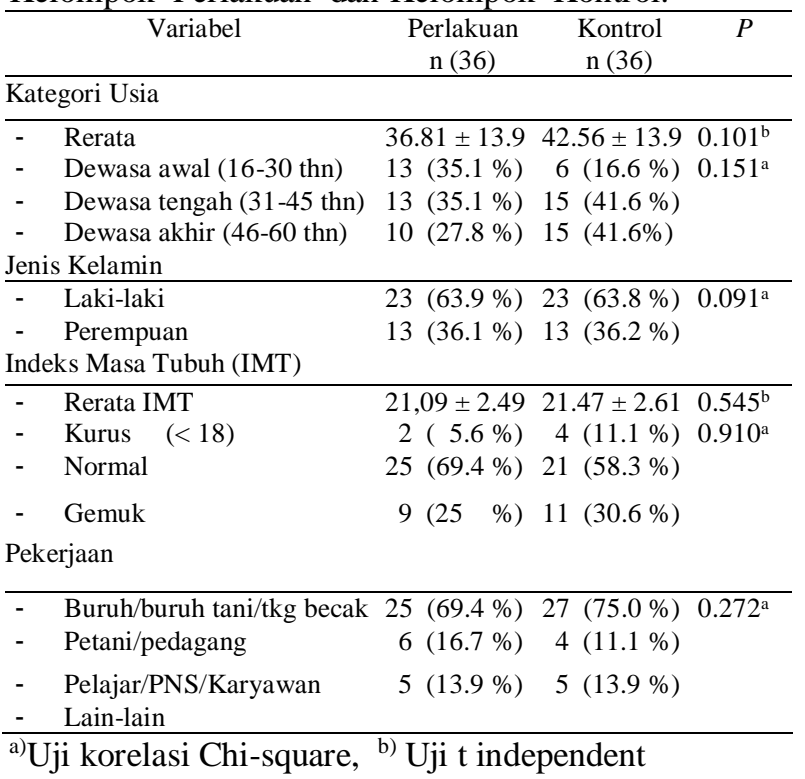

Berdasarkan Tabel 1. dapat disimpulkan bahwa kelompok perlakuan dan kelompok kontrol tidak memiliki perbedaan yang berarti dalam hal rerata usia, jenis kelamin, rerata Indeks Masa Tubuh (IMT), kondisi rumah tinggal dan pekerjaan responden. Data mengenai frekuensi dan rerata faktor risiko reaksi kusta antara kelompok perlakuan dan kelompok kontrol dapat dilihat pada Tabel 2.

Tabel 2. Perbandingan Faktor Risiko Reaksi Kusta, Tipe, dan Derajat Reaksi Antara Kelompok Perlakuan dan Kelompok Kontrol

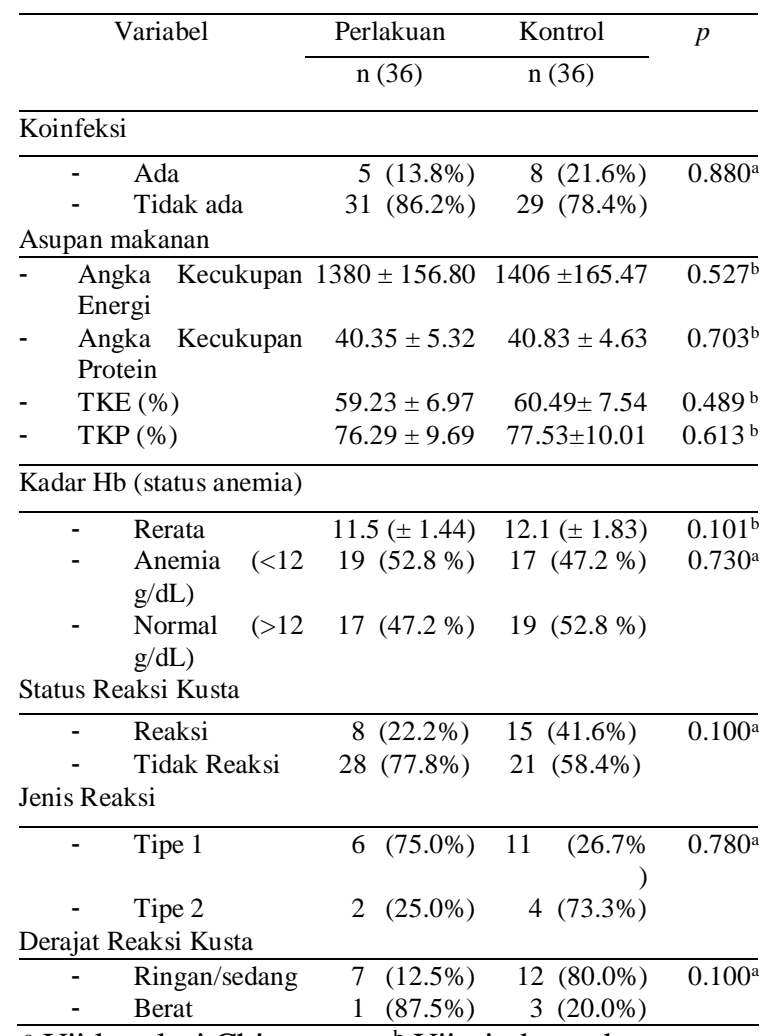

${ }^{\mathrm{a}}$ Uji korelasi Chi-square, ${ }^{\mathrm{b}}$ Uji t independent,

Berdasarkan Tabel 2 menu-njukkan bahwa dilihat dari faktor risiko reaksi pada subyek penelitian yaitu koinfeksi, asupan makanan, status anemia (kadar $\mathrm{Hb}$ ), dan asupan makanan sehari-hari, baik pada kelompok perlakuan maupun kelompok kontrol, secara statistik mendapat-kan hasil tidak terdapat perbedaan yang bermakna. Demikian halnya dengan kadar seng, status reaksi kusta, jenis reaksi serta derajat reaksi kusta. Korelasi antara faktor risiko yang diteliti dengan kejadian reaksi dapat dilihat pada tabel 3 .

Tabel 3. Hubungan Faktor Risiko Koinfeksi, Asupan makanan, Kadar $\mathrm{Hb}$, Kadar Seng serta stress fisik/mental dengan Kejadian Reaksi Kusta.

\begin{tabular}{|c|c|c|c|c|}
\hline Variabel & $\begin{array}{c}\text { Ada } \\
\text { Reaksi Kusta }\end{array}$ & $\begin{array}{c}\text { Tidak ada } \\
\text { Reaksi Kusta }\end{array}$ & OR & $p$ \\
\hline \multicolumn{5}{|l|}{ Koinfeksi } \\
\hline - $\quad$ Ada & $6(26.1 \%)$ & $7(16.7 \%)$ & 1.8 & $0.361^{\mathrm{a}}$ \\
\hline Tidak ada & $17(73.9 \%)$ & $35(83.3 \%)$ & & \\
\hline
\end{tabular}

Asupan makanan

Angka Kecukupan

energi

\begin{tabular}{llllll}
\hline & TKE Cukup & $21(91.3 \%)$ & $22(52.4 \%)$ & 9.5 & $0.002^{\mathrm{a}}$
\end{tabular}

TKE Kurang $\quad 2(8.7 \%) \quad 20(47.6 \%)$

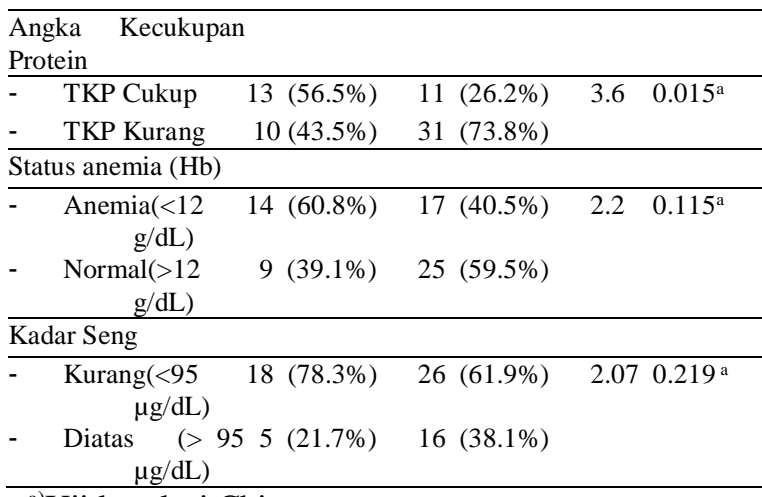

${ }^{\text {a)} U j i ~ k o r e l a s i ~ C h i-s q u a r e ~}$ 
Hasil uji statistik sebagaimana dapat dilihat pada Tabel 3. menunjukkan adanya hubungan yang signifikan antara faktor risiko asupan makanan dengan kejadian reaksi kusta. Untuk faktor risiko status anemia (Kadar $\mathrm{Hb}$ ) dan kadar seng memiliki peran penting dalam mendukung terjadinya reaksi kusta $(\mathrm{OR}>2)$. Perbedaan rerata kadar $\mathrm{Hb}$, Seng, sitokin TNF- $\alpha$, IL-1 $\beta$, dan IL-6 sebelum dan sesudah suplementasi Seng sulfat dosis $40 \mathrm{mg} / \mathrm{hari}$ pada penderita kusta tipe MB disajikan dalam Tabel 4.

Tabel 4. Perbedaan rerata kadar Hb, Seng, TNF- $\alpha$, IL-1 $\beta$, dan IL-6 sebelum dan sesudah suplementasi Seng sulfat dosis $40 \mathrm{mg} / \mathrm{hari}, 12$ minggu.

\begin{tabular}{cccc}
\hline $\begin{array}{c}\text { Variabel / } \\
\text { Pengukuran }\end{array}$ & $\begin{array}{c}\text { Kelompok } \\
\text { Perlakuan }\end{array}$ & $\begin{array}{c}\text { Intervensi } \\
\text { Kontrol }\end{array}$ & $\boldsymbol{p}$ \\
\hline Kadar Hb $(\mathrm{g} / \mathrm{dL})$ & & & \\
\hline - Sebelum & $11.4( \pm 1.44)$ & $12.1( \pm 1.83)$ & $0.095^{b}$ \\
- Sesudah & $11.9( \pm 1.57)$ & $12.1( \pm 1.80)$ & $0.685^{b}$ \\
& $0.044^{a}$ & $0.909^{a}$ & \\
\hline Kadar Seng $(\mu \mathrm{g} / \mathrm{ml})$ & & & \\
\hline & & & \\
\hline - Sebelum & $95.54( \pm 7.41)$ & $95.02( \pm 3.91)$ & $0.761^{b}$ \\
- Sesudah & $93.67( \pm 4.82)$ & $92.00( \pm 4.08)$ & $0.044^{b}$ \\
Kadar & $0.218^{c}$ & $0.001^{c}$ & \\
$(\mathrm{pg} / \mathrm{ml})$ & & & \\
\hline & & & \\
\hline & & & \\
- Sebelum & $21.62( \pm 21.68)$ & $13.82( \pm 13.82)$ & $0.159^{b}$ \\
& $15.28( \pm 14.49)$ & $10.30( \pm 7.91)$ & $0.207^{b}$ \\
& $0.063^{c}$ & $0.221^{c}$ & \\
\hline
\end{tabular}

\begin{tabular}{lccc}
\hline $\begin{array}{l}\text { Kadar } \\
(\mathrm{pg} / \mathrm{ml})\end{array}$ & IL-1 $\beta$ & & \\
& & & \\
\hline - Sebelum & $10.85( \pm 23.64)$ & $3.24( \pm 6.82)$ & $0.549^{b}$ \\
- Sesudah & $3.81( \pm 15.63)$ & $1.20( \pm 0.97)$ & $0.788^{b}$ \\
& $0.032^{c}$ & $0.537^{c}$ &
\end{tabular}

Kadar IL-6 (pg/ml)

$\begin{array}{lccc}\text { - Sebelum } & 17.22( \pm 26.96) & 12.03( \pm 23.72) & 0.966^{b} \\ \text { - Sesudah } & 7.14( \pm 9.65) & 8.12( \pm 13.07) & 0.662^{b} \\ & 0.389^{c} & 0.784^{c} & \end{array}$

Ket: ${ }^{\text {a) }}$ paired $\mathrm{t}$ test ${ }^{\text {b) }}$ Mann-Whitney test ${ }^{\text {c) }}$ Wilcoxcon Signed Ranks test.

Hasil uji statistik sebagai-mana disajikan pada tabel 4 menunjukkan bahwa terdapat perbedaan penurunan yang signifikan rerata kadar $\mathrm{Hb}$ pada kelompok perlakuan, penurunan kadar Seng pada kelompok kontrol, serta kadar IL-1 $\beta$ pada kelompok Perlakuan. Untuk sitokin TNF- $\alpha$ dan IL-6 terjadi penurunan pada kelompok kontrol akan tetapi secara statistik belum signifikan.

Distribusi karakteristik subjek penelitian menunjukkan jumlah subjek laki-laki lebih banyak daripada perempuan. Hasil ini sesuai dengan penelitian sebelumnya oleh Mastrangelo, 2009 di Brazil menunjukkan jumlah pasien kusta laki-laki lebih banyak daripada perempuan.(18) Penyakit kusta lebih sering terjadi pada laki-laki dengan rasio 2:1, sedangkan menurut usia kejadiannya meningkat pada usia 10-14 tahun, selanjutnya menurun diikuti peningkatan lagi pada usia 30-50 tahun.(19). Rerata umur kelompok penderita kusta adalah 45 tahun. Hal tersebut sesuai dengan penelitian Mastrangelo yang menyebutkan bahwa rerata umur pasien kusta adalah 48.06 tahun. ${ }^{18}$. Penyakit kusta memliki masa inkubasi yang lama, sehingga pasien kusta sering ditemukan pada umur remaja hingga dewasa muda. ${ }^{20}$

Berkaitan dengan status gizi, Singh melaporkan bahwa $40.5 \%$ pasien yang mengalami penurunan kadar hemoglobin memiliki body mass index $(\mathrm{BMI})>18.5$ dan $59.5 \%$ kurang dari tersebut. BMI > 18.5 menunjukkan status gizi normal, sedangkan BMI $<18.5$ menunjukkan gizi kurang. ${ }^{21}$. Beberapa penelitian sebelumnya mendapatkan bahwa asupan mikronutrien mempengaruhi respon imunologi pada penderita kusta. Dalam penelitian ini BMI sebagian besar subjek antara kelompok kusta dengan kelompok sehat (non kusta) memiliki BMI normal. Hal ini bertentangan dengan penelitian Fatimah, 2017 yang mendapatkan perbedaan signifikan BMI dan status seng pada penderita kusta dengan kelompok kontrol (bukan kusta). ${ }^{22}$ Sebagian besar subjek penelitian kelompok kusta bekerja sebagai buruh/buruh tani yang pada saat bekerja mendapat asupan makan untuk mencukupi energi saat beraktivitas. Namun jika diamati dari recall $1 \times 24$ jam asupan makanan yang dikonsumsi sebagian besar kelompok kusta lebih sering mengkonsumsi sayur dan sedikit mengkonsumsi asupan makanan bersumber dari protein hewani. Rerata BMI pada kelompok kasus 21.09 dan pada kelompok kontrol 21.47. Hal ini sesuai dengan penelitian Rao, 2009 di India yang menyebutkan bahwa rerata BMI pasien kusta adalah 20.4 $4^{23}$ Studi Montenegro, 2009 di Brasil menunjukkan tidak ada hubungan signifikan antara status gizi dengan terjadinya reaksi kusta, bahwa reaksi ini lebih banyak tidak ditemukan pada kelompok BMI kurang.

Berdasarkan uji statistik, terdapat hubungan antara angka kecukupan energi dan angka kecukupan protein dengan kejadian reaksi kusta. Menurut penelitian Nagari, 2012 bahwa responden yang kurang asupan zat gizi terutama energi dan protein memiliki status gizi kurus. Secara teoritis penderita kusta akan memiliki status gizi kurus akibat katabolisme protein yang meningkat. Jika hal ini tidak didukung dengan pemberian makanan yang cukup protein. Penelitian yang dilakukan oleh Philani, 2008 di Kota Semarang terhadap subjek yang hidup berdampingan dengan penderita kusta mencatat bahwa asupan protein tinggi diperlukan bagi penderita bahkan orang disekitarnya untuk meningkatkan daya tahan tubuh.(Mustamin. Asupan DIIT TKTP dan Status Gizi Pasien Kusta di RS. Dr. Tadjuddin Chalid Makassar. Media Gizi Pangan. 2010; 9(1)) Pasien dengan berat badan kurang tidak memiliki respons imunologis yang cukup akibat tingkat konsumsi energi dan protein yang rendah akan menyebabkan abnormalitas pada imunitas yang ditunjukkan dengan penurunan jumlah limfosit $\mathrm{T}$, penurunan aktivitas sel natural killer, serta penurunan fungsi dari produksi interleukin.

Berkaitan dengan faktor risiko reaksi kusta, hasil uji statistik mendapatkan hubungan antara 
stress fisik/mental dengan kejadian reaksi pada penderita. Hasil penelitian ini sesuai dengan penelitian Shriya Dave, et al 2003 menyatakan bahwa stres fisik/mental yang dialami penderita berhubungan dengan terjadinya reaksi Erythema Nodosum Leprosum (ENL). Stres akibat kelelahan fisik akan berpengaruh terhadap respon imun yang menyebabkan kerentanan terhadap penyakit dan diduga dipengaruhi oleh hormon kortisol. Perubahan keseimbangan hormonal pada penderita kusta akan memicu terjadinya reaksi kusta.

Rerata kadar $\mathrm{Hb}$ pada kelompok kasus 11.5 dan kelompok kontrol 12.1 keduanya berada dibawah kadar $\mathrm{Hb}$ Normal. Menurut WHO kadar $\mathrm{Hb}$ normal laki-laki dewasa $13 \mathrm{~g} / \mathrm{dl}$ dan perempuan dewasa 12 $\mathrm{g} / \mathrm{dl}$, dinyatakan anemia bila kadar $\mathrm{Hb}$ lebih rendah dari batas normal. ${ }^{24}$ Anemia pada penyakit kusta disebabkan karena penyakit kronik, biasanya merupakan anemia defisiensi besi karena terjadi penghancuran zat besi dan iron binding protein oleh makrofag, gangguan metabolisme zat besi serta pelepasan sitokin yang menekan produksi eritroprotein. ${ }^{25}$

Pada penelitian ini mendapatkan hasil rerata kadar seng serum subyek penelitian $( \pm 95 \mu \mathrm{g} / \mathrm{dL})$ dibawah rerata kadar seng manusia sehat $( \pm 104$ $\mu \mathrm{g} / \mathrm{dL}$ ), bila dilihat rerata kadar seng pada kelompok perlakuan setelah mendapat suplementasi Seng sulfat $40 \mathrm{mg} /$ hari selama 12 minggu terdapat penurunan kadar seng sebesar $1,8 \mu \mathrm{g} / \mathrm{dL}$, sedangkan pada kelompok kontrol penurunannya sebesar $3.02 \mu \mathrm{g} / \mathrm{dL}$, dan hasil uji statistik membuktikan terdapat perbedaan yang bermakna antara kadar Seng serum sebelum dan sesudah suplementasi ( $\mathrm{p}$ : 0.003). Rendahnya kadar seng pada penderita kusta dapat menyebabkan multiplikasi bakteri M.leprae karena menurunnya imunitas seluler yang berperan dalam mengeliminasi mikrobakteria. Suplementasi seng pada penderita akan memberikan pengaruh yang baik bagi peningkatan kadar seng serum yang penting bagi perkembangan imunitas seluler.

Kebutuhan intake Seng laki-laki dewasa dalam sehari adalah $11 \mathrm{mg}$ dan perempuan dewasa adalah 8 mg, dan rerata kadar Seng penderita kusta yang pernah reaksi sebelumnya, lebih rendah dibanding penderita yang tidak pernah reaksi pada kelompok kontrol, namun tidak berbeda bermakna. Berdasarkan hasil penelitian ini terdapat perbedaan yang signifikan antara kadar Seng yang mendapat intervensi suplemen Seng $40 \mathrm{mg} / \mathrm{hr}$ dengan kelompok kontrol, hal ini sesuai hasil penelitian sebelumnya As'ad, 2003 bahwa setelah 8 minggu suplementasi kelompok intervensi secara signifikan memiliki konsentrasi seng lebih tinggi daripada kelompok kontrol. ${ }^{26}$

Hasil penelitian ini juga menunjukan peningkatan kadar seng serum dan penurunan kadar TNF- $\alpha$ dan IL6 setelah suplementasi seng, hal ini sesuai dengan penelitian sebelumnya bahwa konsentrasi seng plasma cepat menurun selama respon fase akut untuk stimulasi yang berbeda, tekanan, infeksi, dan trauma. Akibatnya, seng dibongkar ke dalam kompartemen seluler, di mana ia digunakan untuk sintesis protein, netralisasi radikal bebas, dan untuk mencegah invasi mikroba. Redistribusi seng selama inflamasi tampaknya dimediasi oleh sitokin, beberapa penelitian telah menunjukkan bagaimana pasien dengan penyakit akut hadir dengan hipozincemia bersamaan dengan peningkatan produksi sitokin. ${ }^{26,27}$.

Dalam penelitian ini pengukuran variabel perancu Asupan makanan hanya menggunakan metode recall. Variabel sitokin pro-inflamasi sebagai penanda penting munculnya reaksi Kusta yang diteliti hanya TNF- $\alpha$, IL-1 $\beta$ dan IL-6. Pemeriksaan kadar Seng menggunakan sampel serum darah pasien, oleh karena menggunakan subyek yang cukup besar

\section{KESIMPULAN}

Suplementasi Seng sulfat dosis $40 \mathrm{mg} / \mathrm{hr}$ selama 12 minggu mampu mempertahankan penurunan kadar seng serum, serta menurunkan kadar IL-1 $\beta$, namun demikian belum cukup bukti untuk menurunkan kadar TNF- $\alpha$ dan IL-6. Faktor risiko asupan makanan sehari-hari (TKE, TKP) berhubungan dengan kejadian reaksi kusta ( $\mathrm{p}<$ 0.05). Faktor risiko kadar $\mathrm{Hb}$, kadar Seng dan Koinfeksi meskipun tidak bermakna secara statistik $(\mathrm{p}<0.05)$, akan tetapi memiliki peran cukup penting dalam mendukung terjadinya Reaksi Kusta (OR $\geq$ 2).

\section{REFERENSI}

[1] WHO. Guide to Eliminate Leprosy as a Public Health Problem. 1st ed. Switzerland; 2000.

[2] WHO. Epidemiological Review of Leprosy in the Western Pacific Region 2008-2010. Switzerland; 2011.

[3] Khandapani T, Mishra B. Health Problems and Nutrirional Status of Selected le Burla Town, Orissa, India. Curr Res J Soc Sci. 2010;2(6):350-7.

[4] Handog E, Gabriel T, Co C. Leprosy in the Philippines: a Review. Int J Dermatol. 2011;57:573-81.

[5] Saunderson P, Grebe S BP. Reversal Reactions in the Skin Lesions of AMFES Patient. Incidence and Risk Factor. Lepr review 71; 309-317 $\mathrm{p}$.

[6] Britton, WJ LD. Leprosy. Lancet 363; 2004. 1209-1219 p.

[7] Kumar B, Dogra S KI. Epidemiological Characteristic of Leprosy Reactions: 15 Years Experience from North India. Int $\mathrm{J}$ Leprs Other Mycobact Dis. 2004;72:12533.

[8] Departemen Kesehatan RI. Buku Pedoman Nasional Pemberantasan Penyakit Kusta. 17th ed. Jakarta: Direktorat Jenderal Pemberantasan Penyakit Menular dan Penyehatan Lingkungan; 2007. 71-82 p. 
[9] Kawahita IP, Lockwood DN. Towards Understanding the Pathology of Erithema Nodosum Leprosum. An Bras Dermatol. 2008;83:75-82.

[10] Amirudin MD D. Diagnosis Penyakit Kusta, dalam: Adhi Juanda, dkk, Kusta Diagnosis dan Penatalaksanaan. Balai penerbit FKUI; 1997. 1-16 p.

[11] Kementian Kesehatan RI. Laporan Program P2 Kusta. Jakarta: Subdit P2 Kusta, Ditjen PPM \& PLP; 2014.

[12]Dinas Kesehatan Propinsi Jawa Tengah. Profil Kesehatan Provinsi Jawa Tengah 2015. Semarang; 2015.

[13] Oh SY PH and JD. Dietary Habits, Food Intake and Functional Outcomes in Those with a History of Hansen's Disease in Korea. Int J Lepr Other Mycobact Dis. 1998;66:3442.

[14]Diffey B, Vaz M SM et al. The Effect of Leprosy-Induced Deformity on the Nutritional Status of index Cases and Their Household Members in Rural South India: a Socio-Economic Perspective. Eur J Clin Nutr. 2000;54:643-649.

[15]15. Cuevas L, Koyanagi A. Zinc and Infection: a Review. Ann Trop Paediatr. 2005;25:149-60.

[16] 16. Prasad A. Impact of The Discovery of Human Zinc Deficiency on Health. J Am Coll Nutr. 2009;3(28):257-65.

[17] 17. Pradhan T, Kumari S. Evaluation of Oxidative Status And Zinc Level In Leprosy Patients After Zinc Supplementation. Int J Biol Med Res. 2015;2(6):4984-7.

[18] 18. Mastrangelo G, da Silva Neto J, da Silva G, Scoizzato L, Fadda E, Dallapicola M, et al. Leprosy Reactions: the effect of Gender and Household contacts. Mem Inst Oswaldo Cruz. 2011;1(106):92-6.

[19]19. Yawalkar S. Leprosy for Medical Practitioner and Paramedical Workers. 8th ed. Basle Switszerland: Novartis Foundation for Sustainable Development; 2009. 21-3 p.

[20]20. Montenegro R, Zandonade E, Molina Mdel C, Diniz L. Reactional State and Nutritional Profile among Leprosy Patients in the Primary Health care System, Greater
Vitória, Espírito Santo State, Brazil. Cad Saude Publica. 2012;1(28):31-8.

[21]21. Singh H, Nel B, Dey V, Tiwari P, Dulhani N. Adverse Effects of Multi-Drug Therapy in Leprosy, a Two Years' Experience (2006-2008) in Tertiary Health Care Centre in the Tribal Region of Chhattisgarh State (Bastar, Jagdalpur). Lepr Rev. 2011;82:17-24.

[22]22. Fatimah S, Rahfiludin MZ. The Difference of BMI and Micronutrient Intake Between Multibacillary Leprosy and Non Leprosy (A Study in District Brondong, Lamongan 2013). Adv Sci Lett. 2017;23(4):3421-3423(3).

[23]23. Rao P, John A. Nutritional Status of Leprosy Patients in India. Indian J Lepr. 2012;1(84):17-22.

[24]24. Cooper B. Hematologic Diseases Red Cells Approach to Diagnosis and Management of Anemia. In: Brain M, Carbone P, editors. Current Therapy in Hematology Oncology. 5th ed. Mosby: St Louis Missour; 1995. p. 53-104.

[25]25. Erslev A. Anemia of Chronic Disease. In: William J, Beutler E, Erslev A, Lichtman M, editors. Hematology. 4th ed. New York: McGraw Hill; 1991. p. 51822.

[26]26. As'ad S, Yusuf I. Profile and Diarrhea in The Effects of Zinc Supplementation on the TNF-Severely Malnourished Children of Low Income Family. Vol 12, No 4, October - December 2003). 2003;12(4).

[27]27. Yusuf S. Pengaruh pemberian zinc terhadap diare pada tikus yang diinduksi lipopolisakarida (LPS) dari eschericia coli: kajian terhadap sitokin proinflamasi (TNF- $\alpha, I L-6, I L-1)$, zinc, sod, hb dan jumlah sel goblet mukosa usus. Yogyakarta : Universitas Gajah Mada; 2015. 